\title{
BARTŁOMIEJ KUGACZ
}

Uniwersytet Mikołaja Kopernika w Toruniu

bartekkugacz@gmail.com

ORCID: 0000-0003-3451-407X

\section{Prawnokarna ochrona praw pracownika - wybrane zagadnienia}

Penal and legal protection of worker rights - chosen aspects

Streszczenie. Celem niniejszego artykułu jest przybliżenie wybranych zagadnień prawnokarnych statuujących ochronę praw pracownika. W artykule poruszona została tematyka zagadnień, takich jak stosunek pracy oraz wynikających $\mathrm{z}$ niego praw, w szczególności: terminowego otrzymywania wynagrodzenia za pracę, przeciwdziałania mobbingowi oraz przywrócenia do pracy w następstwie orzeczenia odpowiedniego organu. Autor w swoim opracowaniu dąży przede wszystkim do uwypuklenia innych, występujących w całym systemie prawa przepisów (a więc sięgających poza płaszczyznę właściwą jedynie dla prawa pracy), które zawierają instrumenty prawne chroniące prawa pracownika.

Słowa kluczowe: Kodeks pracy; stosunek pracy; Kodeks karny; pracownik; pracodawca; odpowiedzialność karna.

Summary. The point of this article is the discussion of penal and legal issues in the context of worker rights. This article analyzes the relation between work and its rights, such as providing salary on time, countering mobbing, and reinstatement to work as a result of a decision of an appropriate institution. The author of this article strives to emphasize other models which contents concern workers rights as an alternative to the labor code.

Key words: the labor code; the penal code; employee; employer; criminal liability.

Data przesłania artykułu do Redakcji: 21.04.2020 r.

Data akceptacji artykułu przez Redakcję: 24.08.2020 r.

\section{Uwagi wstępne}

Pojęcie stosunku pracy zostało zdefiniowane w artykule 22 Kodeksu Pracy ${ }^{1}$. Zgodnie z jego brzmieniem pracownik zobowiązuje się do wykonania pracy określonego rodzaju na rzecz pracodawcy i pod jego kierownictwem oraz w miejscu i czasie wyznaczonym przez pracodawcę, natomiast pracodawca zobowiązuje się do zatrudnienia pracownika za wynagrodzeniem. Ustawodawca dokonał rozróżnienia pojęć umowy o pracę i stosunku pracy. Stosunek pracy najczęściej nawiązywany jest w oparciu o umowę o pracę, rzadziej natomiast na podstawie:

\footnotetext{
${ }^{1}$ Ustawa z dnia 26 czerwca 1974 r. Kodeks pracy (t.j. Dz. U z 2019 r. poz. 1040 z późn. zm.)
} 
powołania, wyboru, mianowania czy spółdzielczej umowy o prace ${ }^{2}$. Pojęciem stosunku pracy posługuje się ustawodawca również na gruncie przepisów Kodeksu karnego ${ }^{3}$, przy czym nie formułuje on legalnej jego definicji. Praktyka taka jest dopuszczalna, gdyż zgodnie z jedną z cech prawa karnego, tj. subsydiarnością, normy prawa karnego mają charakter pomocniczy względem innych gałęzi systemu prawa. Oznacza to, że można je stosować dla ochrony stosunków społecznych regulowanych przez przepisy np. prawa pracy czy prawa cywilnego, jeżeli rozwiązania prawne w nich przyjęte okażą się być pod kątem ochronnym nieefektywne ${ }^{4}$. W korelacji funkcjonalnej do cechy subsydiarności prawa karnego pozostaje kolejna jego cecha tzw. uniwersalizm. Zgodnie z jej założeniami normy prawa karnego nie regulują wyłącznie jednej, ściśle określonej dziedziny prawa ${ }^{5}$ (co widać na przykładzie intytulacji poszczególnych rozdziałów k.k., np. rozdział XXVIII penalizujący „Przestępstwa przeciwko prawom osób wykonujących pracę zarobkową"). Wskazana transparentność systemu prawa ma wymiar uniwersalny, tzn. nie tylko na płaszczyźnie ochrony praw pracowniczych należy brać pod uwagę normy skodyfikowane w innych gałęziach systemu prawa. Taką praktykę z powodzeniem można zastosować przy określaniu źródeł praw pracowniczych, ponieważ zostały one ujęte nie tylko w Kodeksie pracy, ale również w przepisach ustawy zasadniczej ${ }^{6}$ czy aktach prawa międzynarodowego (art. 9 Konstytucji RP).

W ramach niniejszego artykułu podjęto problematykę odpowiedzialności karnej za naruszenie praw pracowniczych. Celem autora jest przedstawienie najważniejszych praw pracownika wynikających ze stosunku pracy (w rozumieniu przepisu art. $22 \S 1$ k.p.), które podlegają ochronie w ramach tzw. kodeksowego oraz pozakodeksowego prawa karnego, a należy do nich: prawo do wynagrodzenia wypłaconego w terminie, prawo do wykonywania pracy w środowisku wolnym od zachowań mobbingowych oraz prawo do ponownego przyjęcia do pracy, gdy o przywróceniu do pracy orzekł właściwy organ ${ }^{7}$.

\section{Analiza regulacji prawnokarnej}

Przepisy karne chroniące prawa pracownicze w polskim systemie prawnym pojawiły się już w okresie międzywojennym. Były one systematycznie włączane do prawa wykroczeń. W kodeksie karnym z 1932 r. ${ }^{8}$ (tzw. Makarewicza) ustawodawca nie zawarł rozdziału poświęconego ochronie przed bezprawnymi zamachami na prawa pracowników. Do przeciwdziałania zamachom na prawa pracownicze związane $\mathrm{z}$ bhp pomocniczo wykorzystywano przepisy penalizujące przestępstwa

\footnotetext{
${ }^{2}$ W. Muszalski (red.), Kodeks pracy. Komentarz. Wyd. 12, Warszawa 2019

${ }^{3}$ Ustawa z dnia 6 czerwca 1997 r. Kodeks karny (t.j. Dz. U. z 2019 r. poz. 1950 z późn. zm.).

${ }^{4}$ J. Lachowski, A. Marek, Prawo karne-zarys problematyki, Warszawa 2018, s. 19.

5 Tamże.

${ }^{6}$ Konstytucja Rzeczypospolitej Polskiej z dnia 2 kwietnia 1997 r. (Dz. U. Nr 78, poz. 483 z późn. zm.).

${ }^{7}$ Por. art. 218 § 2 Ustawa z dnia 6 czerwca 1997 r. Kodeks karny (t.j. Dz. U. z 2019 r. poz. 1950 z późn. zm.).

${ }^{8}$ Rozporządzenie Prezydenta Rzeczypospolitej z dnia 11 lipca 1932 r. Kodeks Karny (Dz. U. 1932 nr 60 poz. 571 )
} 
przeciwko życiu i zdrowiu czy też przestępstwa urzędnicze ${ }^{9}$. W okresie powojennym ochrona praw pracowniczych zyskała nowe brzmienie spowodowane obowiązująca ówcześnie ideologią. „Troskę“ o dobro pracowników zaakcentowano w przepisach Dekretu z dnia 13 czerwca 1946 r. o przestępstwach szczególnie niebezpiecznych w okresie odbudowy Państwa ${ }^{10}$, a w szczególności z przepisu art. 42. Zawarto w nim, że ,Kto, będąc przełożonym albo pracodawcą, złośliwie lub uporczywie uchyla się od wykonywania ciążącego na nim ustawowego lub społecznego obowiązku dbałości o dobro pracowników i przez to naraża ich na szkodę, podlega karze więzienia do lat 5 lub aresztu"11. Z kolei w świetle przepisów Kodeksu karnego z roku 1969 prawa pracownika ujęte zostały w rozdziale XXVII obejmującym artykuły od 190 do 191. Artykuł 190 Kodeksu karnego z 1969 r. zapewniał ochronę prawną pracownika wynikającą ze stosunku pracy lub przepisów o ubezpieczeniu społecznym. Przepis ten aktualizował się w przypadku naruszenia praw pracowniczych przez osobę odpowiedzialną w zakładzie pracy za sprawy związane z zatrudnieniem.

Współcześnie obowiązująca regulacja kodeksowa, tj. Kodeks Karny z 1997 r. ${ }^{12}$ zawiera cały rozdział poświęcony przestępstwom przeciwko prawom osób wykonujących pracę zarobkową (jest to rozdział XXVIII). Analizie poddany został art. $218 \S 1 \mathrm{a}^{13}$, który stanowi dla niniejszego opracowania podstawą do dalszych rozważań. Dobrem w nim chronionym są prawa wynikające ze stosunku pracy lub ubezpieczeń społecznych. Do znamion strony przedmiotowej omawianego artykułu należy naruszenie praw pracowniczych w sposób złośliwy lub uporczywy. Zatem do zachowań tego typu zaliczyć należy: zachowanie charakteryzujące się złośliwością, chęcią dokuczenia, okazania lekceważenia poprzez nierespektowanie praw pracownika, mimo obiektywnej możliwości, określonego uprawnienia pracowniczego ${ }^{14}$.

Zauważyć należy, że żaden przepis obowiązującego Kodeksu karnego nie definiuje pojęcia pracownika. Definicji takiej nie zawarto również w przepisie art. 115 k.k. Stwarza to podstawy do wysunięcia wniosku de lege ferenda o konieczności zamieszczenia takiej definicji (w tzw. słowniku ustawowym) zwłaszcza, że prawnokarną ochronę pracownika statuuję rozdział XXVIII k.k. Co więcej zabieg taki jest wskazany ze względu na nakaz restrykcyjnego interpretowania pojęć w prawie karnym i niedopuszczalnego (ze względu na jego funkcję gwarancyjną) poszerzania zakresu penalizacji ${ }^{15}$. Zakres merytoryczny pojęcia, ,pracownik” można ustalić na podstawie

\footnotetext{
9 W. Radecki, Komentarz do art. 218 k.k.,[w:]A. Wąsek (red.), Kodeks karny. Część szczególna, Komentarz do artykułów 117-221, Warszawa 2006, s. 1207.

10 Dekret z dnia 13 czerwca 1946 r. o przestępstwach szczególnie niebezpiecznych w okresie odbudowy Państwa, Dz. U. 1946 nr 30 poz. 192

${ }^{11}$ Tamże.

${ }^{12}$ Ustawa z dnia 6 czerwca 1997 r. Kodeks karny (t.j. Dz. U. z 2019 r. poz. 1950 z późn. zm.).

${ }^{13}$ Tamże

${ }^{14}$ Wyrok Sądu Apelacyjnego we Wrocławiu z dnia 30 marca 2016 r. sygn. akt II AKa 71/16.

${ }^{15}$ Uchwała Sądu Najwyższego I KZP 34/05 (OSNKW 2006, nr 1, poz. 2).
} 
przepisu art. 2 k.p. w związku z przepisem art. 22 k.p. ${ }^{16}$. Jest to osoba zatrudniona na podstawie umowy o pracę, powołania, wyboru, mianowania lub spółdzielczej umowy o pracę. Należy jednak zaznaczyć, iż przepis art.218 § 1a k.k. dotyczy jedynie pracownika, więc nie gwarantuje on ochrony prawnej innym osobom niebędącym pracownikami, a świadczącym pracę na podstawie umów cywilnoprawnych $^{17}$. Zasadnicze znaczenie $\mathrm{w}$ procesie sądowego badania, czy dany stosunek prawny jest stosunkiem pracy czy też nie, ma ustalenie czy świadczona praca (podlegająca sądowej weryfikacji) posiada cechy wymienione w przepisie art. $22 \S 1$ k.p. W tym celu bada się okoliczności i warunki, w jakich dana osoba wykonuje czynności na rzecz innego podmiotu $\operatorname{prawa}^{18}$. Należy również wysunąć postulaty de lege ferenda, aby ochroną art. $218 \S 1$ a k.k. objąć również osoby pozostające $\mathrm{w}$ stosunku zatrudnienia innym niż stosunek pracy. Wspomnieć należy również, iż każde zatrudnienie noszące cechy stosunku pracy jest z mocy prawa traktowane jako zatrudnienie w ramach stosunku pracy bez względu na nazwę zawartej przez strony umowy ${ }^{19}$.

Zakres ochrony wynikający z przepisu art. $218 \S 1 \mathrm{a}$ k.k. nie obejmuje prawa do ponownego przyjęcia do pracy ani ochrony życia i zdrowia pracownika, niemniej kwestii tych dotyczy odpowiednio: art.218 § 2 k.k. oraz art. $220 \S 1$ k.k. Przepis art. 218 § 1a k.k. nie penalizuje również naruszania praw wynikających ze stosunku pracy obejmującego zbiorowe prawa pracy oraz prawa zrzeszania się w związki zawodowe, które są regulowane odrębnymi ustawami ${ }^{20}$.

\section{Praca jako wartość konstytucyjna}

Konstytucjonalizacja zagadnienie z zakresu prawa pracy, świadczyć może o przekonaniu ustrojodawcy o jej szczególnej roli dla prawidłowego funkcjonowania demokratycznego państwa prawa. Co za tym idzie fakt uwzględnienia pracy wśród przepisów ustawy zasadniczej świadczyć może o szczególnej potrzebie jej ochrony.

Przepis artykułu 24 Konstytucji RP nakłada obowiązek ochrony pracy przez państwo (tj. władze państwowe) ${ }^{21}$. Zauważyć należy, że ustawa zasadnicza chroni ,,pracę’, a nie ,prawo do pracy” jak to miało miejsce w przepisie art. 19 ust. 1 Konstytucji Rzeczypospolitej Ludowej ${ }^{22}$. W orzecznictwie wskazuje się, że przepis art. 24 Konstytucji RP zawiera deklarację objęcia ochroną warunków, zakresu i treści świadczenia i przyjmowania pracy w ramach zarówno stosunku pracy, jak i świadczenia pracy, które odbywają się w obrębie stosunków cywilnoprawnych oraz innego

\footnotetext{
${ }^{16}$ Ustawa z dnia. 26 czerwca 1974 r. Kodeks pracy (t.j. Dz. U z 2019 r. poz. 1040 z późn. zm.)

${ }^{17}$ A. Wąsek, R. Zawłocki (red.), Kodeks karny. Czesść szczególna. Komentarz do artykułów 117-221, Tom I, Warszawa 2010, s. 1213.

${ }^{18}$ Uchwała Sądu Najwyższego z dnia 20 września 2018 r. I KZP 5/18 (OSNKW 2018, nr 11, poz.74).

${ }^{19}$ Tamże

${ }^{20}$ Tamże.

${ }^{21}$ M. Safjan, L. Bosek (red.), Konstytucja RP, Komentarz do art. 1-86, Warszawa 2016, Legalis/el.

${ }^{22}$ Konstytucja Polskiej Rzeczypospolitej Ludowej z dnia 22 lipca 1952 r. (Dz.U. 1952 nr 33 poz. 232).
} 
rodzaju zatrudnienia ${ }^{23}$. Uznać należy, iż praca jest wartością samą w sobie, jako szczególne dobro stanowi ona podstawę funkcjonowania gospodarki ${ }^{24}$. Konstytucja RP nie definiuje pracy, pozostawia w tym miejscu przestrzeń dla definicji wypracowanych na płaszczyźnie np. nurtów filozoficznych czy religijnych. Praca ujęta w przepisie Konstytucji RP nie odnosi się wyłącznie do pracy wykonywanej w ramach stosunku pracy, lecz do pracy sensu largo, tj. do pracy wykonywanej na rzecz innego podmiotu na podstawie umowy o pracę czy też innej umowy za wynagrodzeniem lub bez świadczenia wzajemnego w postaci wolontariatu, czy pracy obowiązkowej ${ }^{25}$. Przepis art. 24 Konstytucji RP określa również zakres merytoryczny ochrony trwałości zatrudnienia. Wynika to z konieczności zapewnienia pracownikowi bezpieczeństwa socjalnego, na które składa się nie tylko zapewnienie przychodów, ale także ochrony na płaszczyźnie świadczeń społecznych, a także ochrona godności pracownika ${ }^{26}$.

\section{Obowiązek wypłacenia wynagrodzenia w terminie}

Obowiązek wypłacenia wynagrodzenia chroniony jest przez regulację prawnokarną, jako jedno ze znamion czynu zabronionego penalizowanego w przepisie art. 218 § 1a k.k. oraz art. $218 \S 3$ k.k. Pojęcie ,wynagrodzenia za pracę” nie posiada definicji legalnej zawartej w k.p. Można ją wyinterpretować w oparciu o brzmienie przepisu art. 80 k.p. Przed określeniem zakresu merytorycznego pojęcia ,wynagrodzenia za pracę” należy najpierw wyjaśnić czym jest „wykonanie pracy”, ponieważ wynagrodzenie przysługuje w zamian za nie. Przez „wykonanie pracy” należy rozumieć spełnienie przez pracownika jego obowiązku, dołożenia należytej sumienności i staranności oraz stosowania się do poleceń przełożonych, które dotyczą pracy, jeżeli nie są one sprzeczne z przepisami prawa lub umowy o pracę ${ }^{27}$. Pracodawca nie może również być zwolniony z obowiązku wypłacenia wynagrodzenia za pracę $\mathrm{z}$ tego powodu, że stanowi to dla niego obciążenie finansowe ${ }^{28}$. Wynagrodzenie jest to obowiązkowe świadczenie okresowe podmiotu zatrudniającego, posiadające wartość majątkową, spełniane na rzecz pracownika w ramach stosunku pracy w zamian za świadczoną przez niego pracę ${ }^{29}$. Należy zwrócić również uwagę na szczególną ochronę wynagrodzenia wynikającą z przepisu art. 84 k.p. Zgodnie z jego brzmieniem pracownik świadczący pracę nie może ani zrzec się wynagrodzenia, ani przenieść prawa do wynagrodzenia na inną osobę.

\footnotetext{
${ }^{23}$ Wyrok Trybunału Konstytucyjnego z dnia 22 maja 2013 r. P 46/11 (OTK-A 2013 nr 4, poz. 42).

${ }^{24}$ Tamże.

${ }^{25}$ M. Safjan, L. Bosek (red.), Konstytucja RP, Komentarz do art. 1-86, Warszawa 2016, Legalis/el.

${ }^{26}$ Wyrok Trybunału Konstytucyjnego z dnia 22 maja 2013 r. P 46/11 (OTK-A 2013 nr 4, poz.42).

${ }^{27}$ Zob. art. $100 \S 1$ k.p.

28 Wyrok SN z dnia 11 stycznia 2006 r. II PK 113/05 (OSNP 2006, nr 23-24, poz. 348).

${ }^{29}$ P. Daniluk Komentarz do art. 218 k.k., w: Kodeks karny. Komentarz, R.A. Stefański (red.), Warszawa 2018, Legalis/el.
} 
Przepis zawierający czyn, który jest wykroczeniem przeciwko prawom pracownika został zaimplikowany $\mathrm{w}$ art. $282 \S 1$ k.p. sygnalizującym na penalizację zachowania pracodawcy polegającym na niewypłaceniu $\mathrm{w}$ ustalonym terminie wynagrodzenia za pracę lub innego świadczenia przysługującego pracownikowi ${ }^{30}$ oraz artykuł 281 k.p. określający katalog wykroczeń przeciwko prawom pracownika.

Regulacja przepisu z art. $218 \S 1$ a k.k. zawiera typ kwalifikowany wykroczenia wskazanego w przepisie art. 281 k.p. oraz przepisie art. 282 k.p, a znamieniem kwalifikującym jest działanie sprawcy charakteryzujące się złośliwością lub uporczywością ${ }^{31}$. Należy zwrócić uwagę również na przepis art. $218 \S 3$ k.k. Strona podmiotowa przestępstwa w nim stypizowanego wskazuje, iż jest to czyn umyślny (który można popełnić w zamiarze bezpośrednim jak i ewentualnym ${ }^{32}$ ) i obejmuje on swoim zakresem merytorycznym stan faktyczny wskazany w przepisie art. $282 \S 2$ k.p. (czyli niewykonanie orzeczenia sądu zobowiązującego do wypłaty wynagrodzenia za pracę lub innego świadczenia wynikającego ze stosunku pracy). Podkreślić należy, iż termin „innego świadczenia ze stosunku pracy” zawarto w przepisie art. 218 § 3 k.k. Co więcej, uprawnionymi do tego ,świadczenia” mogą być też członkowie rodziny pracownika, którego prawa zostały naruszone ${ }^{33}$. Jako przykład powołać się można na przepis art. 93 k.p. określający zasady nabycia odprawy pośmiertnej. Zgodnie z przepisem art. 93 § 1 k.p.: „,W razie śmierci pracownika w czasie jego trwania stosunku pracy lub w czasie pobierania po jego rozwiązaniu zasiłku z tytułu niezdolności do pracy wskutek choroby, rodzinie przysługuje od pracodawcy odprawa pośmiertna”. W związku z tym przepis art. $218 \S 3$ k.k. obejmuje ochroną prawa pracownika, jak i prawa jego rodziny (wynikające $\mathrm{z}$ faktu świadczenia przez niego pracy) ${ }^{34}$.

Obowiązek zapłaty wynagrodzenia jest tzw. długiem oddawczym. Pracodawca jest obowiązany przesłać pracownikowi wynagrodzenie na własny koszt i niebezpieczeństwo na wskazany przez niego rachunek płatniczy ${ }^{35}$.

\section{Mobbing jako przesłanka wszczęcia postępowania karnego na podstawie art. 218 § 1a k.k.}

Pojęcie mobbingu zostało zdefiniowane w 1984 r. przez Heinza Leymanna, szwedzkiego psychiatrę i psychosocjologa niemieckiego pochodzenia. Autor ten twierdził, że mobbing istniał zawsze, nigdy

\footnotetext{
${ }^{30}$ Zob. art. $286 \S 1$ pkt 1 k.p.

${ }^{31}$ E. Hrynkiewicz-Lach, Komentarz do art. 218 k.k., w: Kodeks karny. Czesść szczególna, Komentarz do art. 117- 221, M. Królikowski, R. Zawłocki (red.), Warszawa 2017, Legalis/el.

${ }^{32}$ A. Ziółkowska, Komentarz do art. 218 k.k., w: Kodeks karny. Komentarz, V. Konarska-Wrzosek (red.), Warszawa 2018, s. 1046.

${ }^{33}$ Tamże.

${ }^{34}$ Por. art. $93 \S 1$ k.p.

${ }^{35}$ E. Maniewska Komentarz do art. 8 k.p., w: K. Jaskowski, E. Maniewska, Kodeks pracy. Komentarz, Warszawa 2019 , LEX/el.
} 
jednak nie był wcześniej badany ani opisywany w sposób systematyczny ${ }^{36}$. W polskiej przestrzeni prawnej termin ten pojawił się wraz z nowelizacją Kodeksu pracy z dnia 14 października 2003 r. Przed wprowadzeniem do języka prawnego pojęcia mobbingu orzecznictwo Sądu Najwyższego dopuszczało dochodzenie przez pracownika roszczeń od pracodawcy z tytułu naruszenia dóbr osobistych $^{37}$. Zjawiska mobbingu expressis verbis dotyczy przepis art. $94^{3} \S 2$ k.p. zgodnie, z którym: mobbing jest działaniem lub zachowaniem dotyczącym pracownika lub skierowanym przeciwko pracownikowi, który polega na uporczywym i długotrwałym nękaniu lub zastraszaniu pracownika, czym wywołuje się u niego zaniżoną ocenę przydatności zawodowej, powodując lub mając na celu poniżenie lub ośmieszenie pracownika, izolowanie go lub wyeliminowanie z zespołu współpracowników ${ }^{38}$. Należy mieć na uwadze, iż wszystkie wymienione przesłanki w przepisie art. $94^{3} \S 2$ k.p. musza być spełnione łącznie, aby zachowanie wypełniało cechy zachowania mobbingowego ${ }^{39}$. Jak podkreśla się $\mathrm{w}$ orzecznictwie Sądu Najwyższego, wskazane przesłanki mobbingu muszą zaistnieć obiektywnie, aby $\mathrm{W}$ połączeniu $\mathrm{z}$ subiektywnymi odczuciami pracownika złożyły się one na zjawisko mobbingu. Samo stwierdzenie wystąpienia takiego zjawiska nie może zostać oparte na subiektywnych odczuciach pracownika, ale musi być rozpatrzone w szerszym kontekście wynikającym z rozsądnego postrzegania rzeczywistości, prowadzącej do właściwej oceny intencji drugiej osoby w określonych relacjach społecznych ${ }^{40}$.

W ramach zakładu pracy tworzona jest pewnego rodzaju przestrzeń, w której człowiek realizuje swoją wolność pracy ${ }^{41}$. Człowiek w życiu prywatnym, jak i w czasie pracy ma prawo do ochrony swoich praw i wolności. Państwo poprzez regulacje prawne zawarte w szczególności w Kodeksie pracy czy Kodeksie karnym umożliwia jednostce ochronę przysługujących jej praw. Istotnym elementem ochrony praw i wolności w świetle prawa pracy jest pracodawca, na którego państwo nakłada obowiązek zapobiegania swoistym sytuacją patologicznym w postaci mobbingu, dyskryminacji czy nierównego traktowania. Obowiązek ten sprawowany jest w imieniu państwa, będący przejawem działalności administracyjnej ${ }^{42}$. Należy zauważyć, iż Kodeks pracy reguluje wyłącznie zachowania prewencyjne w postaci obowiązku zapobiegania sytuacji mobbingu przez pracodawcę $\mathrm{w}$ celu ochrony pracowników. Przepis art. $94^{3} \S 1$ k.p. ustanawia wyłącznie zobowiązanie pracodawcy do zapobiegania patologicznym sytuacjom w miejscu pracy. Należy

36 H. Leymann, The Mobbing Encyklopedia, Bullying; Whistleblowing, 1996; źródło: http://www.leymann.se/5marca2010 [dostęp: 05.04.2020], w: J. Kowal, G. Pilarek, Mobbing jako problem etyki w zarządzaniu, Annales. Etyka w życiu gospodarczym 2011, vol. 14, nr 1, s. 227-240.

${ }^{37} \mathrm{G}$. Jędrejek, Dochodzenie roszczeń zwiąanych z mobbingiem, dyskryminacja i molestowaniem, Warszawa 2017 , s. 18.

${ }^{38}$ Zob. art. $94^{4} \S 2$ k.p.

${ }^{39}$ Wyrok Sądu Najwyższego z dnia 11 lutego 2014 r., I PK 165/13.

${ }^{40}$ Wyrok Sądu Najwyższego z dnia 11 lutego 2014 r. I PK 165/13.

41 A. Sobczyk, Mobbing a przeciwdziałanie mobbingowi. Dyskryminacja a przeciwdziałanie dyskryminacji, Monitor Prawa Pracy 2015, nr 4, s. 174.

42 Tamże. 
uznać, iż pracodawca za zaniechanie obowiązku wyrażonego w art. $94^{3} \S 1$ k.p. powinien również odpowiadać. Podkreślić należy, iż omawiany przepis ma charakter publicznoprawny co implikuje, iż prawo do świadczenia pracy w warunkach wolnych od mobbingu należy się pracownikowi nie w zamian za pracę na rzecz pracodawcy, ale dlatego, że jest członkiem społeczności, którą prawo chroni przed negatywnymi zdarzeniami mogącymi mieć ujemny wpływ na realizację prawa do godnego życia ${ }^{43}$.

Zgodnie z dyspozycją przepisu art. 218 § 1a k.k. mobbingu może dopuścić się każdy, kto wykonuje czynności w sprawach z zakresu prawa pracy i ubezpieczeń społecznych, jest to więc przestępstwo indywidualne. Oznacza to, iż taki czyn zabroniony może popełnić jedynie osoba ściśle określona. W tym przypadku może to być pracodawca, pod warunkiem, że jest osobą fizyczną osobiście wykonującą określone czynności z zakresu pracy i ubezpieczeń społecznych ${ }^{44}$. W sytuacji, gdy wskazane rodzaje czynności wykonuje ktoś inny niż pracodawca lub jeżeli pracodawcą jest jednostka organizacyjna, to wówczas sprawcą komentowanego typu przestępstwa może być odpowiednio: osoba pełniąca funkcje zarządzające albo jedynie wchodząca w skład organu zarządzającego lub tworzącego, a także inna osoba delegowana do wykonywania tychże czynności ${ }^{45}$.

Od strony podmiotowej przestępstwo penalizowane w przepisie art. 218 § 1a k.k. polega na działaniu umyślnym w zamiarze bezpośrednim ${ }^{46}$. Złośliwość i uporczywość wynikająca z przepisów artykułu $218 \S$ 1a k.k. polega na chęci sprawienia pracownikowi przykrości lub dolegliwości bądź działaniu uporczywym, co znaczy, że dany akt naruszenia powtarza się lub trwa przez dłuższy czas ${ }^{47}$. Zjawiska wskazane w ustawie karnej pokrywają się z przejawami zjawiska mobbingu w sensie psychospołecznym. Naruszenie godności pracownika (by było ono przejawem mobbingu) musi kumulatywnie charakteryzować się: po pierwsze, określonym czasem (przyjmuje się, że nie krótszym niż pół roku), po drugie, określonym zachowaniem się sprawcy (nękanie polegać powinno na ciągłym, powtarzalnym - bo występującym przynajmniej raz w tygodniu - świadomym oraz celowym podejmowaniem działań przez sprawcę względem ofiary mobbingu $)^{48}$. Należy zwrócić również uwagę na fakt, że dla możliwości wyciągnięcia prawnokarnych konsekwencji nie jest istotne wystąpienie skutku w postaci zachowań mobbingowych w rozumieniu przepisu art. $94^{3} \S 2$ k.p., ale wystarczy samo naruszenie prawa

\footnotetext{
${ }^{43}$ D. Dörre-Kolasa, Komentarz do art. $94^{3}$ K.p., w: Kodeks pracy. Komentarz, A. Sobczyk (red.), Warszawa 2015.

${ }^{44}$ A. Ziółkowska, Komentarz do art. 218 k.k., w: Kodeks karny. Komentarz, V. Konarska-Wrzosek (red.), Warszawa 2018, LEX/el.

${ }^{45}$ Tamże.

${ }^{46}$ J. Piórkowska-Flieger, Komentarz do art. 218 k.k., w: Kodeks karny. Komentarz, T. Bojarski (red.), Warszawa 2016, LEX/el.

${ }^{47}$ Tamże.

${ }^{48}$ L. Grzesiuk, Mobbing w miejscu pracy - czynniki ryzyka i konsekwencje, w: Zdrowie i choroba. Problemy teorii, diagnozy i praktyki, J.M. Brzeziński, L. Cierpiałowska (red.), GWP, Gdańsk 2008, s. 230. Cyt. za: J. Kowal, G. Pilarek, Mobbing jako problem etyki..., s. 227-240.
} 
pracownika wynikającego ze stosunku pracy (tj. naruszenie obowiązku przeciwdziałania mobbingowi w miejscu pracy lub w związku z pracą). Świadczy to o formalnym charakterze przepisu art. $218 \S 1 \mathrm{a}$ k.k..

\section{Odmowa ponownego przyjęcia do pracy o której przywróceniu orzekł właściwy organ}

Czynność wykonawcza wskazana w przepisie art. $218 \S 2$ k.k. polega na ponownym nieprzyjęciu do pracy osoby, o której przywróceniu orzekł właściwy organ. W związku z tym przestępstwo to można popełnić poprzez zaniechanie. Może ono przybrać postać fizycznego uniemożliwienia uprawnionemu pracownikowi podjęcia pracy (niewpuszczenie na teren zakładu), może polegać na sformułowaniu ustnego lub pisemnego zakazu wykonywania pracy, może ostatecznie polegać na pełnej bierności osób odpowiedzialnych u określonego pracodawcy za organizację warunków pracy (np. niewydanie odzieży roboczej, karty pracy, kluczy itp.) ${ }^{49}$. Odpowiedzialność za wyżej określone przestępstwo wchodzi w grę w sytuacji, kiedy w razie ustalenia, że wypowiedzenie umowy o pracę zawartej na czas nieokreślony jest nieuzasadnione lub narusza przepisy o wypowiedzeniu umów o pracę, sąd pracy - stosownie do żądania pracownika orzeka o bezskuteczności wypowiedzenia, a jeżeli umowa uległa już rozwiązaniu - o przywróceniu pracownika do pracy na poprzednich warunkach albo o odszkodowaniu ${ }^{50}$. Sytuację analogiczną do tej z przepisu art. $218 \S 2$ k.k. wskazano w przepisie art. $56 \S 1$ k.p. Zgodnie z jego brzmieniem pracownikowi, z którym rozwiązano umowę o pracę bez wypowiedzenia z naruszeniem przepisów o rozwiązaniu umowy o pracę w tym trybie, przysługuje roszczenie o przywrócenie do pracy na poprzednich warunkach albo o odszkodowanie. O przywróceniu do pracy lub odszkodowaniu orzeka sąd pracy ${ }^{51}$. Jak wskazuje Sąd Najwyższy: ,zakład pracy obowiązany jest zatrudnić pracownika, któremu wypowiedziano umowę o pracę (warunki pracy i płacy) w sposób niezgodny z prawem lub nieuzasadniony, z chwilą uprawomocnienia się orzeczenia o bezskuteczności wypowiedzenia lub o przywróceniu pracownika do pracy" ${ }^{\natural 2}$. Należy zwrócić uwagę również na fakt, iż pracownik może domagać się zatrudnienia na tym samym stanowisku, które zajmował uprzednio, zaś nie wystarczy zapewnić mu stanowiska równorzędnego ${ }^{53}$.

Przestępstwo z przepisu art. $218 \S 2$ k.k. zostaje więc popełnione w momencie, kiedy pracownik przywrócony do pracy prawomocnym orzeczeniem sądu zgłasza się do pracy w terminie 7 dni gotowy do podjęcia pracy, a osoba wykonująca czynności z zakresu prawa pracy odmawia mu

\footnotetext{
${ }^{49}$ W. Wróbel, Komentarz do art. 218 k.k., w: Kodeks karny. Część szczególna. Komentarz do art. art. 212-277, W. Wróbel, Z. Andrzej (red.), Warszawa, 2017, LEX/el.

${ }^{50}$ Zob. art. 56 k.p.

${ }^{51}$ Zob. art. 56 k.p.

${ }^{52}$ Uchwała Sądu Najwyższego z dnia 27 kwietnia 1977 r. I PZP 3/77 (OSNC 1977, nr 9).

${ }^{53}$ Wyrok Sądu Najwyższego z dnia 2 grudnia 1992 r. I PRN 55/92.
} 
powzięcia wyżej założonego zamiaru ${ }^{54}$. Odmowa taka nie musi mieć charakteru uporczywego lub złośliwego by spełniać znamiona czynu zabronionego określonego w przepisie art. $218 \S 1 \mathrm{a} \mathrm{k.k}{ }^{55}$.

\section{Wnioski}

Praca jest jednym z tych aspektów odwiecznych i pierwszoplanowych, zawsze aktualnych i wciąż na nowo domagających się, by o niej myśleć ${ }^{56}$. Pojęcie pracy towarzyszy ludziom od zarania dziejów jednak poprzez wieki zakres merytoryczny pracy ewoluował. Można powiedzieć, że praca stanowi znaczną część życia każdego człowieka, dlatego świadomość odnośnie praw, jakie nam przysługują z racji wykonywanej czynności w postaci świadczenia pracy, jest niezbędna w celu realizacji własnych praw, jak i przestrzeganiu praw innych osób.

Przedstawione rozważania odnieść należy również do przesłanek czynu zabronionego penalizowanego w przepisie art. 218 § 1a k.k., które wymagają, aby działanie sprawcy przestępstwa charakteryzowało się ,złośliwością” i ,uporczywością”. Ich rola jest zasadnicza, ponieważ pozwalają one m.in. na odróżnienie komentowanego występku penalizowanego w Kodeksie karnym od innych naruszeń praw pracowniczych zawartych m.in. w Kodeksie pracy. Odpowiedzialność karna, postrzegana w nauce prawa karnego jako instrument ultima ratio powinna być stosowana tylko w przypadkach na to niewątpliwie zasługujących ${ }^{57}$. W związku z tym uznać należy, że przesłanki odpowiedzialności karnej za naruszenie praw pracownika mają węższy zakres merytoryczny niż przesłanki odpowiedzialności za naruszenie praw pracownika wypracowane na gruncie prawa pracy $^{58}$, co należy ocenić pozytywnie, gdyż stanowi to przejaw zróżnicowania form reakcji represyjnej, jakie może stosować władza publiczna za czyn zabroniony. Kształt dyspozycji przepisu art. $218 \S$ 1a k.k. można traktować jako przypisanie prawu karnemu zdolności dyscyplinującego oddziaływania na jednostki w kierunku zaniechania popełniania społecznie szkodliwych zachowań ${ }^{59}$. Za w pełni uzasadnione należy uznać twierdzenie, iż kryminalizacja naruszań praw pracownika wzmocniła wydźwięk ich ochrony oraz wywarła skutki prewencji ogólnej w świetle ich przestrzegania.

\section{Bibliografia:}

\section{Akty prawne}

Konstytucja Rzeczypospolitej Polskiej z dnia 2 kwietnia 1997 r. (Dz. U. Nr 78, poz. 483)

Konstytucja Polskiej Rzeczypospolitej Ludowej z dnia 22 lipca 1952 r. (Dz.U. 1952 r. Nr 33, poz. 232)

Ustawa z dnia 26 czerwca 1974 r. Kodeks pracy (t.j. Dz. U z 2019 r. poz. 1040 z późn. zm.)

Ustawa z dnia 6 czerwca 1997 r. Kodeks karny (t.j. Dz. U. z 2019 r. poz. 1950 z późn. zm.).

\footnotetext{
${ }^{54}$ W. Radecki, Komentarz do art. 218 k.k..., s. 1218.

${ }^{55}$ W. Wróbel, Komentarz do art. 218 k.k. ..., LEX/el.

${ }^{56}$ Jan Paweł II, Laborem exercenes, Watykan 1981, s. 1

${ }^{57}$ K. Janczukowicz, Naruszenie praw pracownika w orzecznictwie sąów karnych, 2017, LEX/el.

${ }^{58}$ Tamże.

59 E. Hrynkiewicz-Lach, Kara kryminalna wświetle Konstytucji RP, Warszawa 2015, s. 216.
} 
Dekret z dnia 13 czerwca 1946 r. o przestępstwach szczególnie niebezpiecznych w okresie odbudowy Państwa

Rozporządzenie Prezydenta Rzeczypospolitej z dnia 11 lipca 1932 r. Kodeks Karny (Dz. U. 1932 r. Nr 60, poz. 571)

\section{Orzecznictwo}

Wyrok Trybunału Konstytucyjnego z dnia 22 maja 2013 r. P 46/11 (OTK-A 2013 r. Nr 42 poz. 42)

Uchwała Sądu Najwyższego z dnia 20 września 2018 r. I KZP 5/18 (OSNKW 2018 r. Nr 11 poz.74)

Wyrok Sądu Najwyższego z dnia 11 stycznia 2006 r. II PK 113/05 (OSNP 2006 r. Nr 23-24 poz.348)

Wyrok Sądu Najwyższego z dnia 11 lutego 2014 r. I PK 165/13

Wyrok Sądu Najwyższego z dnia 2 grudnia 1992 r. I PRN 55/92

Wyrok Sądu Najwyższego z dnia 11 lutego 2014 r., I PK 165/13

Uchwała Sądu Najwyższego z dnia 27 kwietnia 1977 r. I PZP 3/77 (OSNC 1977 r. Nr 9)

Uchwała Sądu Najwyższego z dnia 15 grudnia 2005 r. I KZP 34/05 (OSNKW 2006 r. Nr 1 poz. 2)

Wyrok Sądu Apelacyjnego we Wrocławiu z dnia 30 marca 2016 r. II AKa 71/16

\section{Literatura}

D. Dorre - Kolasa, Komentarz do art. $94^{3}$ K.p., w: Kodeks pracy. Komentarz, A. Sobczyk (red.), Warszawa 2015

L. Grzesiuk, Mobbing w miejscu pracy - czynniki ryzyka i konsekwencje, w: Zdrowie i choroba. Problemy teorii, diagnozy i praktyki, J.M. Brzeziński, L. Cierpiałowska (red.), Gdańsk 2008

E. Hrynkiewicz-Lach, Kara kryminalna w świetle Konstytucji RP, Warszawa 2015

J. Kowal, G. Pilarek, Mobbing jako problem etyki w zarządzaniu, Annales. Etyka w życiu gospodarczym 2011, vol. 14, nr 1, s. 227-240

M. Królikowski, R. Zawłocki, Kodeks karny .Część szczególna. Komentarz do artykułów 117-221, Warszawa 2017

V. Konarska-Wrzosek (red.), Kodeks karny. Komentarz, Warszawa 2018, LEX/el.

K. Janczukowicz, Naruszenie praw pracownika w orzecznictwie sadów karnych, 2017, LEX/el.

G. Jędrejek, Dochodzenie roszczeń związanych z mobbingiem, dyskryminacja i molestowaniem, Warszawa 2017

J. Lachowski, A. Marek, Prawo karne - zarys problematyki, Warszawa 2018

H. Leymann, The Mobbing Encyklopedia, Bullying; Whistleblowing, 1996; źródło: http://www.leymann.se/5marca2010 [dostęp: 05.04.2020]

E. Maniewska. Komentarz do art. 8 k.p., w: K. Jaśkowski, E. Maniewska, Kodeks pracy. Komentarz, Warszawa 2019, LEX/el.

W. Muszalski (red.), Kodeks pracy. Komentarz Warszawa 2019

J. Piórkowska-Flieger, Komentarz do art. 218 k.k., w: T. Bojarski (red.), Kodeks karny. Komentarz,

T. Bojarski (red.)Warszawa 2016 LEX/el.

W. Radecki, Komentarz do art. 218 k.k., w: Kodeks karny. Część szczególna. Komentarz do art. 117-221,

A. Wąsek (red.), Warszawa 2006

K. Rączka, Komentarz do art. 14 k.p.,w: M. Gersdorf, K. Rączka, M. Raczkowski, Kodeks pracy. Komentarz, Warszawa 2014

M. Safjan, L. Bosek (red.), Konstytucja RP, Komentarz do art. 1-86, Warszawa 2016

R.A. Stefański (red.), Kodeks karny. Komentarz, Warszawa 2018

A. Sobczyk (red.), Mobbing a przeciwdziałanie mobbingowi. Dyskryminacja a przeciwdziałanie dyskryminacji, Monitor Prawa Pracy 2015, nr 4

A. Wąsek, R. Zawłocki (red.), Kodeks karny. Czesść szczególna. Komentarz do art. 117-221, Tom I, Warszawa 2010

W. Wróbel, Komentarz do art. 218 k.k., w: Kodeks karny. Część szczególna. Komentarz do art. 212-277,

W. Wróbel, A. Zoll (red.), Warszawa 2017 